\title{
O sentido da morte para protestantes e neopetencostais ${ }^{1}$
}

\author{
Ana Keila Mosca Pinezi² \\ Universidade Federal do ABC, Santo André-SP, Brasil
}

\begin{abstract}
Resumo: Este artigo tem por objetivo compreender e interpretar o sentido da morte para dois grupos evangélicos distintos, um neopentecostal da Igreja Internacional da Graça de Deus e outro protestante histórico de vertente presbiteriana, ambos localizados em Ribeirão Preto-SP. Foram realizadas etnografia em cultos e reuniões das denominações, entrevistas abertas com fiéis e observação participante. Os dados coletados foram analisados comparativamente. A pesquisa demonstrou que a noção de esperança dos presbiterianos está atrelada ao reencontro no céu e à vitória sobre a morte por meio da vida eterna e da segunda vinda de Jesus Cristo. A morte, entre eles, é desnaturalizada e ritualizada. Em contraposição, os neopentecostais vêem a morte como uma ruptura natural da vida, sem ritualizá-la no espaço sagrado. Para eles, a morte opõe-se à busca incessante, no presente, das bênçãos divinais, em especial as materiais e as relacionadas à cura do corpo.
\end{abstract}

Palavras-chave: crenças religiosas, esperança, ritos de morte.

\section{The meaning of death attributed by protestants and neo-pentecostals}

\begin{abstract}
This article aims to understand and interpret the meaning two different protestant groups, located in Ribeirão PretoSP, Brazil, attribute to death. One is the International Church of the Grace of God, a neopentecostal church and a traditional one, presbyterian. Ethnography was employed during the services and meetings of both churches in addition to open-ended interviews with participant observation. Collected data were compared. Results revealed that the presbyterians' concept of hope is linked to meeting again in heaven and victory over death through eternal life and the second coming of Jesus Christ. Death for them is denaturalized and ritualistic. In contrast, neopentecostals view death as a natural rupture of life and do not ritualize it in the sacred space. In their view, death is opposed to the endless search for divine blessings, especially material ones and those related to healing the body.
\end{abstract}

Keywords: religious beliefs, hope, death rites.

\section{EI sentido de la muerte para protestantes e neopetencostales}

Resumen: Este trabajo trata del sentido de la muerte para dos grupos evangélicos distintos, uno neopentecostal de la Iglesia Internacional de la Gracia de Dios y el otro protestante histórico de vertiente presbiteriana, ambos localizados en la ciudad de Ribeirão Preto-SP, Brasil. Fue realizada etnografía en cultos y reuniones de las denominaciones, entrevistas abiertas con fieles y observación participante. Los datos recolectados fueron analizados comparativamente. La investigación demostró que la noción de esperanza de los presbiterianos está sujeta al reencuentro en el cielo y a la victoria sobre la muerte por medio de la vida eterna y del segundo retorno de Jesucristo. La muerte, entre ellos, es desnaturalizada y ritualizada. En contraposición, los neopentecostales ven la muerte como una ruptura natural de la vida, sin ritualizarla en el espacio sagrado. Para ellos la muerte se opone a la busca incesante, en el presente, de las bendiciones divinas, en especial las materiales y las relacionadas con la curación del cuerpo.

Palabras clave: creencias religiosas, esperanza, ritos de muerte.

Saio da vida como de uma casa de hóspedes, e não de uma casa em que se mora.

Cícero

O presente artigo constitui um desdobramento de trabalho de pesquisa feito sobre a noção de esperança entre dois grupos evangélicos distintos. Ao investigar como os referidos grupos construíram a noção de esperança, a temática da morte apareceu fortemente, pois a finitude humana traz consigo a busca de respostas sobrenaturais que tragam consolo e que alimentem a esperança na vida após a morte.

1 O presente artigo deriva da Tese de doutorado da autora defendida no Programa de Pós-graduação em Psicologia da Faculdade de Filosofia, Ciências e Letras de Ribeirão Preto da Universidade de São Paulo.

2 Endereço para correspondência:

Profa. Dra. Ana Keila Mosca Pinezi. Universidade Federal do ABC Centro de Engenharia, Modelagem e Ciências Sociais Aplicadas. Rua Santa Adélia, 166, Bloco B. CEP 09.210-170. Santo André-SP, Brasil. E-mail: ana.pinezi@ufabc.edu.br
Neste trabalho, consideramos a religião como um sistema cultural, como propõe o antropólogo norte-americano Clifford Geertz, um caminho interessante na medida em que nos pode proporcionar orientações gerais que nos auxiliem a tratar de questões específicas. Geertz $(1978$, p. 104) parte da idéia de que "a religião é um sistema de símbolos". Essa definição implica outra que a explica: a de que os padrões culturais são "sistemas ou complexos de símbolos" (p. 106), daí a idéia de religião como um sistema cultural. Essa definição, no entanto, depende de um aprofundamento sobre o que se quer expressar com a palavra símbolo. Os símbolos são formulações plenas de significado porque remetem a experiências abstratas materializadas ou a idéias, conceitos, sensações e atitudes que foram condensadas e concretizadas. A cruz vazia para os protestantes, por exemplo, simboliza duas lembranças de experiências distintas do Cristo: a morte e a vitória sobre ela.

Geertz (1978) traça outras características essenciais dos símbolos. Eles são uma espécie de programa com códigos 
estabelecidos, que, por sua vez, funcionam como modeladores ou ordenadores de processos e comportamentos no âmbito público. Em razão de nortearem comportamentos e processos externos ou públicos, os símbolos são observáveis como qualquer outro fato social. Sobre isso Geertz (p. 105) argumenta que: "Os atos culturais, a construção, apreensão e utilização de formas simbólicas, são acontecimentos sociais como quaisquer outros; são tão públicos como o casamento e tão observáveis como a agricultura".

Os símbolos modelam a realidade e ao mesmo tempo se modelam a ela. São as duas faces da mesma "moeda" chamadas por Geertz (1978, p. 109) de "modelo 'de' e modelo 'para' a realidade". Dentro dessa perspectiva, os símbolos religiosos modelam o mundo, "induzindo o crente a um certo conjunto distinto de disposições (tendências, capacidades, propensões, habilidades, hábitos, compromissos, inclinações) que emprestam um caráter crônico ao fluxo de sua atividade e à qualidade da sua experiência" (p. 109).

O símbolo religioso deve ser um inquestionável estatuto de verdade e, para que assim seja visto, essa verdade deve transcender as verdades da lógica humana, deve guardar um mistério que a vincule com o sobrenatural impedindo que seja de alguma forma ameaçada. Os símbolos, como ordenadores e orientadores da conduta dos indivíduos, precisam sempre ser alimentados e relembrados por essa verdade inquestionável porque se vierem a ruir, instalar-se-á o caos, que segundo Geertz (1978), significa a perda de sentido, a impossibilidade de interpretar e compreender os acontecimentos da vida. Por isso, os símbolos, em especial os símbolos sagrados, precisam ser legitimados pela própria obediência dos indivíduos à sua significância.

É preciso que enfatizemos que toda a argumentação sobre a necessária manutenção e constante legitimação dos símbolos não contraria o pressuposto de que estes não são estáticos, fixos. Se eles são unidades significativas das quais os homens se valem para construir e modelar a realidade que se mostra dinâmica, então os símbolos também guardam um caráter dinâmico. Daí o reconhecimento de que a visão da morte e do porvir, entre os dois grupos evangélicos estudados neste trabalho, está em constante mudança, embora os pilares fundamentais sejam arduamente preservados no discurso de cada geração.

A religião, como sistema cultural, mostra-se como uma fonte produtora de sentido e de respostas para os que a procuram e no que se refere à morte não é diferente. A esperança de uma outra vida ou da continuidade após a morte tem, na maioria das religiões, um espaço privilegiado onde se exercita a fé e se constrói o sentido de viver. A vinculação entre a vida presente e o porvir "celestial" é marcante na teologia evangélica. No entanto, há matizes dos mais diversos que caracterizam as inúmeras vertentes evangélicas. Assim, compreendê-los significa chegar ao núcleo das representações que fornece as referências de como pensar e sentir a realidade da morte.

Portanto, este trabalho trata de questões relativas à morte entre protestantes históricos, de linha presbiteriana, e neopentecostais, fiéis da Igreja Internacional da Graça de Deus, dois grupos distintos de evangélicos. Entre os presbiterianos, evangélicos tradicionais, a base teológica que informa a noção de morte é a idéia do devir, constituído pela vida eterna e pela segunda vinda de Jesus Cristo, dimensões privilegiadas para a reafirmação e reprodução da esperança. Já para os neopentecostais da Igreja Internacional da Graça de Deus, o foco de sua teologia é a esperança nas benesses da vida presente, do "aqui e agora", do "tomar posse" das bênçãos divinas para uma vida mais confortável, mais próspera (em termos financeiros materiais) e com mais saúde (em especial, apontando para a "cura divina").

Neste artigo, a morte e o morrer são vistos não somente como um acontecimento da dimensão natural, mas também cultural, por envolver valores, signos, representações, significados, interdições e regras sociais. Isso significa pensálo do ponto de vista da coletividade, já que a morte de um indivíduo diz respeito à experiência vivenciada pelos outros. A experiência da vida pertence a nós e aos outros, mas a da morte, apesar de individualizada, é socialmente partilhada com os vivos e por estes expressa por meio dos tempos e das gerações. É essa a perspectiva da morte neste trabalho, sintetizada nas palavras de Loureiro (2000, p. 95):

Sabemos que vivemos e que morremos, mas, da vida, podemos falar por um conhecimento vivido, atestado por vivenciar a situação, o fenômeno. Porém, falar da morte é sempre algo estranho a nós mesmos, pois o fenômeno só é conhecido em experiência com os outros. Da morte, somos, conscientemente, apenas meros espectadores. A nossa própria morte não podemos atestar. Não voltamos para descrevê-la em nós mesmos. Podemos falar, tentar exprimi-la, mas sua análise dá-se no fenômeno situado no outro, registrado, contado pelos sobreviventes.

\section{Breve histórico sobre os evangélicos e suas diversas vertentes}

A Reforma Protestante, ocorrida no século XVI na Europa, trouxe em sua constituição uma ampla diversidade de vertentes que, ao contrário do Catolicismo, não foi capaz de unificá-las. Portanto, pode-se falar em "protestantismos" (Mendonça, 1995), pois há diferentes vertentes da Igreja Reformada tais como o luteranismo, o calvinismo, o metodismo. Essa diversidade complexificou-se ainda mais depois do protestantismo ter se instalado, por meio de intensa imigração, na América do Norte.

Na América Latina, a partir da primeira metade do século XIX, o protestantismo começa a chegar e a primeira corrente evangélica a se desenvolver ficou conhecida como "protestantismo de imigração". Por questões políticas e econômicas, a América Latina, almejando adentrar o processo de modernização e estabelecer uma economia de livre comércio, oferece incentivos à imigração européia. Assim, 
vêm para a América Latina anglicanos, episcopais (anglicanos norte-americanos) e luteranos. As igrejas por eles aqui estabelecidas são caracterizadas pela preservação vigorosa dos elementos étnicos e culturais de seus países (Gutiérrez, 1996). Além disso, essas igrejas "étnicas", voltadas para os imigrantes instalados na América Latina, estabelecem uma relação de alteridade com a cultura latino-americana e se mostram como uma religiosidade estranha à nova realidade. Dessa forma, o "protestantismo de imigração", caracterizado por um pastorado com grau elevado de escolaridade, por uma religiosidade centrada nas raízes culturais dos imigrantes e segundo um modelo democrático formalizado europeu, tem pouco impacto na América Latina e acaba por se fechar em si mesmo (Mendonça, 1995).

A chamada "segunda corrente evangélica" (Gutiérrez, 1996) ocorreu por meio da vinda de missionários, nos anos 1850, notadamente norte-americanos para a América Latina. Ao contrário do "protestantismo de imigração", o "protestantismo de missão" ou "protestantismo de conversão" voltavase não para as comunidades norte-americanas instaladas na América Latina, mas para a população nativa, com o objetivo de implementar um campo missionário que a levasse à conversão (Mendonça, 1995).

De acordo com a classificação de Gutiérrez (1996), a "terceira corrente" que ocorreu na América Latina foi caracterizada pelas chamadas "missões de fé", que foram feitas por cristãos descontentes com o proselitismo missionário das igrejas do protestantismo histórico e se lançaram ao campo missionário por meio de sociedades interdenominacionais (como a Missão Internacional Centro-Americana, a Aliança Cristã e Missionária e a União Evangélica da América do Sul).

Por fim, em termos de América Latina, ocorreu a "quarta corrente evangélica" representada pelos movimentos pentecostais. A igreja Assembléia de Deus é o maior ícone do pentecostalismo na América Latina (Mendonça, 1995). Também podem ser incluídas nessa corrente as igrejas do pentecostalismo missionário, fruto do trabalho de missionários procedentes de países europeus e as igrejas do pentecostalismo "criollo" (Gutiérrez, 1996), que nasceram pelas mãos de pastores e leigos nativos, como ocorreu no Brasil, com a fundação da Igreja O Brasil para Cristo.

No Brasil, o presbiterianismo teve início com a chegada, em 1859, do missionário norte-americano Ashbel Green Simonton, vindo do norte dos EUA. Fixou-se no Rio de Janeiro onde fundou, em 1862, a primeira Igreja Presbiteriana. Em termos de organização eclesiástica, a Igreja Presbiteriana tem sua hierarquia estabelecida num sistema federativo, claramente verticalizado, embora as igrejas locais gozem de certa autonomia.

Quanto à liturgia na Igreja Presbiteriana do Brasil (IPB), segundo Mendonça (1995, p. 37), é uma "liturgia livre e discursiva; a pregação é predominantemente moralista, pois a salvação situa-se no plano da ética negativa".

Durante o século XIX, as igrejas protestantes norteamericanas passaram por movimentos conhecidos como "reavivamentos". As igrejas protestantes, que já haviam sido influenciadas pelo metodismo, acabaram por aderir ao movimento de "santidade" (Holiness), conceito de John Wesley, cuja teologia foi a base para a fundação da Igreja Metodista. Wesley enfatizava uma vida cristã perfeita, marcada pela conversão e por uma vida de santificação, processo pelo qual o fiel se tornaria cada vez mais "santo" diante de Deus. As igrejas protestantes que aderiram ao movimento de "santidade", nos Estados Unidos, foram as que se transformaram em pentecostais, liderando um surto pentecostal, principalmente, por toda a América Latina. O início, então, do Pentecostalismo se deu nos Estados Unidos, mais precisamente na Escola Bíblica de Topeka, Kansas, onde o pastor Charles Pahram, baseado nos trechos bíblicos sobre o "Dia de Pentecostes", concluiu que o batismo do Espírito Santo, pessoa da Trindade capaz de realizar o processo de santificação e ratificar a conversão, era evidenciado através da glossolalia ou do falar em línguas estranhas (Mendonça, 1995).

Em 1910, foi fundada a primeira igreja pentecostal no Brasil, a Congregação Cristã no Brasil (Freston, 1994; Mariano, 1999). Outra igreja importante, nesse cenário de pentecostalização, foi a Igreja Nova Vida, fundada, no Rio de Janeiro, em 1960, por um missionário canadense. A Nova Vida introduziu o episcopado e voltou-se para as camadas médias da população, com uma doutrina que valorizava a prosperidade financeira. Portanto, a Nova Vida, claramente influenciada pela "Teologia da Prosperidade", já em curso nos Estados Unidos, abre caminho para uma nova concepção da ação de Deus na vida cotidiana do ser humano. Edir Macedo e R. R. Soares, hoje líderes das duas igrejas neopentecostais de maior expressão, a Igreja Universal do Reino de Deus e a Igreja Internacional da Graça de Deus, respectivamente, foram membros da Igreja Nova Vida.

No final dos anos 1970, uma forma diferenciada de organização e discurso pentecostais começa a despontar. Em termos teológicos, as "novas" pentecostais ou as neopentecostais alteram os principais suportes da doutrina protestante e da doutrina escatológica e soteriológica do "pentecostalismo clássico". No que se refere à organização eclesiástica, o neopentecostalismo mescla alguns formatos organizacionais como a combinação do sistema congregacionalista e do episcopal em que há uma centralização de poder nas figuras do "bispo", do "missionário" ou do "apóstolo".

A Igreja Universal do Reino de Deus (IURD), primeira igreja neopentecostal brasileira, foi fundada em 9 de julho de 1977, funcionando inicialmente em uma ex-funerária do subúrbio do Rio de Janeiro, sob a liderança de Edir Macedo e Romildo Ribeiro Soares (Mariano, 1999). Romildo Soares, diante da liderança carismática e do discurso enfático e autoritário de Macedo, deixou a IURD e fundou, em 1980, a Igreja Internacional da Graça de Deus (Mariano, 1999; Campos, 1997).

As neopentecostais enfatizam, em sua doutrina, a "guerra espiritual" entre o bem e o mal, a cura divina, o exorcismo, o transe, a subjetividade individual expressa por catarses e 
surtos emocionais, as crenças mágico-religiosas, a glossolalia como sinal do batismo do Espírito Santo e também uma relação com o sagrado que se baseia numa troca em que o fiel, por meio da fé, oferece seus bens, especificamente seu dinheiro, e recebe de Deus as bênçãos relativas a esse oferecimento (Romanelli \& Pinezi, 2003). A teologia da prosperidade, em todas as áreas da vida, é central na doutrina das neopentecostais que reforçam um convite, principalmente à população pobre, para a resolução dos problemas cotidianos por meio do mote "Pare de sofrer". O neopentecostalismo ressignifica, mediante o processo de sacralização, os elementos simbólicos mais vinculados ao capitalismo e à sociedade de consumo da modernidade.

Este trabalho teve por objetivo compreender e interpretar como dois grupos religiosos evangélicos, um neopentecostal e outro protestante histórico, constróem a noção de presente e futuro e como pensam a esperança diante da finitude humana.

\section{Método}

\section{Participantes}

Foram entrevistados quatro casais de cada grupo religioso, sendo que os cônjuges foram entrevistados separadamente, perfazendo um total de 16 entrevistas. As entrevistas foram realizadas separadamente para evitar que o depoimento de um cônjuge influenciasse o do outro. Os entrevistados tinham entre 24 e 37 anos e frequentavam assiduamente as reuniões e cultos dos grupos religiosos a que pertenciam. Essa faixa etária foi estabelecida em função da idéia de que esses casais poderiam demonstrar o grau de expectativas quanto ao futuro, já que, no Brasil, as pessoas de tal faixa etária encontram-se em uma intensa busca por empregos ou melhores empregos, estabilidade financeira e estruturação ou reestruturação familiar. Uma vez que a pesquisa tinha como foco compreender a noção de esperança, esses jovens casais poderiam demonstrar mais claramente o que esperavam da vida e do futuro em um momento de construção do núcleo familiar, de educação dos filhos pequenos e de busca de estabilidade profissional. A escolha por fazer as entrevistas com casais deve-se ao fato de possibilitar vislumbrar a noção de esperança entre homens e mulheres, dentro do pressuposto de que seriam diferentes essas noções, exatamente pelas diferenças de gênero, ou seja, o objetivo foi verificar se as questões relativas a gênero influenciavam de forma relevante a construção da noção de esperança.

Quanto ao número de entrevistados, a escolha inicial de quatro casais por igreja foi mantida porque houve uma saturação dos dados, ou seja, os dados repetiram-se nas entrevistas e, além disso, atenderam ao escopo do trabalho como sendo suficientes para realizar uma análise qualitativa. É importante destacar que, neste artigo, a análise foi feita com base principalmente na observação de funerais e de cultos.

\section{Procedimentos}

Foram escolhidas duas igrejas evangélicas com visões distintas sobre a forma pela qual a divindade atua sobre a vida dos indivíduos. Uma, a presbiteriana, cuja doutrina teológica volta-se para o "celeste porvir", a outra, Igreja Internacional da Graça de Deus, mostra-se uma igreja "imediatista", voltada para a solução dos problemas da vida terrenal. A questão da morte e a forma como esses adeptos religiosos reagem diante dela é a temática deste trabalho, que constitui apenas uma das partes de uma pesquisa mais abrangente, feita com esses dois grupos, sobre a idéia de céu e de esperança (Pinezi, 2006). Portanto, foram retirados e aqui transcritos alguns depoimentos, fruto de entrevista, que versavam sobre a questão da morte especificamente.

Levando-se em conta os objetivos deste trabalho, a pesquisa está embasada nos pressupostos teórico-metodológicos fornecidos pela Antropologia. Esta se identificou, como outras ciências sociais, com métodos de pesquisa chamados qualitativos. O método etnográfico é uma marca registrada da Antropologia e se mostrou, neste trabalho, uma estratégia metodológica bastante eficaz para a coleta de dados, uma vez que está intimamente vinculado à pesquisa de campo. Por aproximadamente dois anos, foi feita etnografia entre os membros dos dois grupos religiosos em questão.

A etnografia, um estudo descritivo das relações sociais de um povo ou uma comunidade específica, pressupõe contato direto com o "outro". Isto nos pareceu interessante na medida em que a realidade social de um determinado grupo, construída a partir de uma trama entre "atores" sociais, ocorre em um tempo e espaço em que o pesquisador pode adentrar. Além disso, a opção que se fez foi por uma "descrição densa" (Geertz, 1978, p. 17) do que se observa. Ou seja, não uma mera descrição do que se vê ou se ouve, mas uma descrição que considere as "teias de significados" (Geertz, 1978) existentes em toda e qualquer forma de expressão do homem pensado como ser social.

É importante frisar que a etnografia, como estudo descritivo, exige do pesquisador uma postura bastante definida diante do "outro", isto é, a identidade do pesquisador deve ser claramente exposta ao grupo pesquisado, o que faz parte de uma relação verdadeira de alteridade e de ética. É nessa base, inclusive, que se dá a própria observação participante. Ela é fundamental na medida em que a presença do observador numa dada situação social é demonstrada claramente aos observados no sentido de lhes explicitar que essa observação tem como finalidade a investigação científica de suas relações sociais. Existe, então, no processo da observação participante uma relação próxima entre o observador e o observado. $\mathrm{O}$ observador passa a participar da vida dos observados em seu cenário natural, é nessa relação direta entre eles que irá colher seus dados, passando a ser parte do contexto observado. A consciência dessa interação é extremamente importante. É com base nela que a observação participante foi feita e registrada em diário de campo. 
Dentro dessa perspectiva, a observação participante foi realizada nos cultos, nos estudos bíblicos, nos rituais de Santa Ceia e Batismo, nas comemorações de datas especiais, nos rituais de "profissão de fé" (momento em que o neófito, diante da igreja, proclama sua fé e conversão a Jesus Cristo), nos momentos de informalidade e comensalidade, nas vigílias de oração e nos ofícios fúnebres, sobre os quais nos debruçamos neste trabalho. As impressões, os acontecimentos, os pequenos incidentes e o corriqueiro foram registrados em diário de campo. Não se tratou de uma anotação superficial, o tom do comportamento que acompanha as ações e as falas foi nele registrado com a finalidade de apontar um significado que estaria ausente em um registro puro e simples de detalhes de um acontecimento.

Posteriormente, todas as observações foram registradas em diário de campo, longe do local de entrevista, dos cultos e dos rituais. Além da observação participante feita nos cultos das igrejas estudadas, foram realizadas entrevistas abertas com casais adeptos a elas. O processo de entrevistas com os adeptos dos dois grupos religiosos foi feito de forma a explicitar-lhes, inicialmente, o objetivo da entrevista e a posição de pesquisadora de quem a realiza.

O contato inicial com os adeptos desses grupos religiosos foi feito de forma direta, no espaço da igreja. Aqueles que se dispuseram a ser entrevistados tiveram liberdade para marcar o local, a data e o horário para tal. A eles foi dito que as informações concedidas seriam utilizadas na elaboração de trabalho científico e que o nome do entrevistado seria fictício, a fim de preservar sua identidade. Foi solicitada, ainda, autorização a cada um para a utilização de gravador no momento das entrevistas, que posteriormente foram transcritas na íntegra, da forma mais fiel. Portanto, não foi feita uma mera transcrição do conteúdo das fitas de entrevista, mas sim uma transcrição que retratasse, inclusive, os momentos de silêncio, de suspiro, de choro, de riso, de tremor da voz dentro de um contexto que possibilitasse trazer à luz o significado dessas e de outras tantas expressões. A observação participante, registrada em diário de campo, foi feita também nos lares dos informantes e em outros locais, onde as entrevistas foram realizadas, tais como no templo da Igreja da Graça e no gabinete pastoral.

Ainda sobre o processo de entrevistas, foi utilizado um roteiro semi-estruturado, com base nos objetivos da pesquisa e na observação participante feita nos cultos e reuniões desses grupos religiosos. Esse roteiro, no entanto, não significou a realização de uma entrevista fechada. Ao contrário, seu objetivo foi ordenar alguns parâmetros para que se pudesse realizar uma entrevista aberta, em forma de diálogo entre entrevistado e entrevistador. Assim, a entrevista foi considerada como um processo e não como um produto da pesquisa empírica (Romanelli, 1998). As perguntas feitas aos casais estavam relacionadas, basicamente, à idéia de conversão, de experiência espiritual, da vida na terra e no céu, de esperança, de futuro e do que representa a igreja para a vida pessoal.

\section{Breve contextualização dos grupos evangélicos estudados}

Os dois grupos religiosos pesquisados são evangélicos. Um é presbiteriano, denominação que se enquadra na categoria de evangélico protestante histórico. O outro é o da Igreja Internacional da Graça de Deus, considerado um grupo evangélico neopentecostal.

Os pentecostais e os neopentecostais adotam formas emocionalizadas nos rituais sagrados (Mariano, 1999), enquanto os protestantes históricos, principalmente os de linha calvinista, como é o caso dos presbiterianos, têm uma postura mais racionalista em seus rituais. $\mathrm{O}$ tradicionalismo predomina nas denominações protestantes históricas e há uma liturgia ritual que se fundamenta na rotinização das práticas e dos discursos (Mendonça, 2000). Entre os pentecostais, em especial entre os neopentecostais, o carisma (Rivera, 2001) é elemento estruturador dos cultos e alavanca a idéia de que esses grupos se constituem como uma renovação da fé, pelo "reavivamento", realizado pelo Espírito Santo, em contraste com o tradicionalismo protestante.

Embora possamos classificar as diferentes vertentes evangélicas, há especificidades internas no que diz respeito não só ao universo evangélico, mas às denominações ditas protestantes históricas e, especialmente, às pentecostais e neopentecostais, deixando clara a diversidade evangélica e as peculiaridades de cada igreja em cada vertente. Pensemos, então, nas especificidades dos dois grupos aqui em foco.

A igreja evangélica de raiz protestante histórica estudada faz parte da vertente Presbiteriana do Brasil, localizada na região central de Ribeirão Preto-SP. O templo da igreja é uma construção relativamente antiga e comporta aproximadamente 500 pessoas. É considerada uma igreja tradicional, os cultos e as reuniões são realizados de acordo com uma liturgia pré-elaborada. $\mathrm{O}$ momento da pregação da mensagem pelo pastor é considerado o principal nos cultos. A música também faz parte da liturgia que se faz ouvir por meio dos corais da igreja e de um breve momento de "louvor" (de cânticos) conduzido por grupos jovens. A Bíblia é o referencial usado em todos os cultos e reuniões dos presbiterianos.

A igreja evangélica neopentecostal estudada é a Internacional da Graça de Deus, comumente chamada Igreja da Graça. Ela também se localiza na cidade de Ribeirão Preto. Há outras igrejas da mesma denominação nesta cidade, mas a estudada é a maior delas e considerada a sede das outras. Os fiéis reúnem-se num salão amplo, é uma comunidade religiosa que tem seus cultos e reuniões marcados por expressões verbais e gestuais que caracterizam formas extremamente emocionalizadas de demonstrar devoção a Deus (Pinezi, 2007). O período de louvor a Deus por meio da música é intenso e extenso. Além do momento da mensagem do pastor ou do missionário, há um espaço para que os fiéis dêem testemunhos da manifestação divina em suas vidas, enfatizando a cura de doenças, a inserção no mercado de trabalho e a libertação de vícios como o alcoolismo. A Bíblia também é referenciada nos cultos e reuniões desse grupo neopentecostal. 
Ao contrário dos presbiterianos, a comunidade da Igreja da Graça enfatiza, em seus cultos, a guerra espiritual travada invisivelmente entre as hostes malignas, demoníacas, e as legiões de anjos de Deus. Em termos de constituição social dessas igrejas, a Presbiteriana é formada, principalmente, por camadas médias da população ribeirão-pretana. Há uma relação direta com a tradição protestante que historicamente aliou-se às camadas burguesas da sociedade brasileira, pois sustentava e legitimava seus interesses por intermédio de sua doutrina racionalista. Além disso, no caso do presbiterianismo, calcado no calvinismo, a extrema importância dada por essa corrente reformada ao "consciente", à "compreensão intelectual" e às "decisões morais" acabou por afastála das populações menos letradas e excluídas socialmente (Mendonça, 2000).

Predominam no pentecostalismo e no neopentecostalismo membros das camadas populares da população. Isso se deve ao fato de que essas vertentes oferecem uma mensagem evangelística mais acessível aos não letrados, centrada na resolução dos problemas do dia-a-dia, suprimindo, assim, a visão escatológica do mundo, propondo uma saída para a exclusão social por meio de um pragmatismo que envolve atos de fé e de coragem como forma de transformar a condição de vida do adepto. Portanto, na Igreja Internacional da Graça de Deus, há também predominância de membros oriundos das camadas populares, embora, em situações-limite, principalmente no que se refere às questões de ordem familiar e de problemas de saúde, pode-se ver a frequência nos cultos, ainda que não assídua, de indivíduos de camadas mais elevadas economicamente, que buscam soluções divinas para esses problemas de difícil solução em outras esferas da vida social.

Os negros no Brasil foram e continuam a ser excluídos socialmente e constituem a maior parcela da população pobre brasileira. Portanto, a presença de um número elevado de negros na Igreja Internacional da Graça de Deus também corrobora para a afirmação de que há maior atração das camadas populares por essa igreja.

\section{Análise de dados}

Os dados foram analisados à luz da teoria interpretativa da cultura, proposta por Geertz (1978), que pressupõe uma etnografia densa, como foi dito acima. Tal teoria interpretativa, segundo Geertz, está voltada à interpretação do ethos e da visão de mundo de um grupo específico. Esclarecemos as noções de ethos e visão de mundo de acordo com a definição proposta por Geertz (1978, p. 143):

O "ethos" de um povo é o tom, o caráter e a qualidade de sua vida, seu estilo moral e estético e sua disposição, é a atitude subjacente em relação a ele mesmo e ao seu mundo que a vida reflete. A visão de mundo que esse povo tem é o quadro que elabora das coisas como elas são na simples realidade, seu conceito de natureza, de si mesmo, da sociedade. Esse quadro contém suas idéias mais abrangentes sobre a ordem.
Os dados foram trabalhados a partir de uma abordagem qualitativa. "A construção de fatos etnográficos" (Romanelli, 1998, p. 125) foi feita em uma perspectiva interpretativa, levando em consideração a densidade da etnografia da qual emergem representações feitas pelos grupos religiosos em relação à realidade. Nesses termos, a etnografia é pensada como uma forma de "construir uma leitura de" (Geertz, 1978, p. 20). Ainda em relação ao tratamento que tiveram os dados coletados, realizou-se uma análise comparativa entre os dois grupos religiosos em questão. O método comparativo utilizado fundamenta-se em uma comparação feita mediante uma perspectiva relacional que comporta contrastes, oposições e contradições.

\section{Resultados e Discussão}

\section{A morte para os presbiterianos e para os neopentecostais: uma análise comparativa}

Nesta seção, descreveremos e discutiremos as observações feitas e alguns depoimentos dos membros dos grupos religiosos em foco.

Há um dilema, entre os presbiterianos, que parece acompanhá-los durante a vida aqui na terra. Que Deus é esse que fez tantos milagres e curas, registrados nas Escrituras Sagradas, e hoje, sem uma lógica aparente, não atende em determinadas situações, pelo menos positivamente, aos pedidos dos seus filhos? É possível colocar-se como um arauto que proclama as maravilhas de Deus e seus feitos em situações extremas, como a da morte, sem que haja a possibilidade de se submeter à decepção e constrangimento de uma resposta contrária ao pedido cheio de fé? Qual é a lógica de Deus quando cura aquele que não o teme e deixa morrer o fiel, o justo? Como explicar isso? Falta de fé? Vontade divina? Mistérios divinos? Todas essas perguntas levam a uma questão sumária: o que se pode esperar de Deus? Essa questão é crucial para compreender como esses protestantes históricos, em comparação com os da Igreja Internacional da Graça de Deus, uma neopentecostal, constróem e vivenciam a esperança diante dos fatos da vida, em especial o da morte.

O pentecostalismo e o neopentecostalismo desafiam os protestantes históricos no que se refere a todas essas questões e aparecem como a voz que os acusa de não terem fé suficiente para que Deus opere os milagres de cura, prosperidade e restauração. A morte parece estar muito distante, principalmente para os neopentecostais, não só simbolicamente, mas também na prática religiosa, pois não há, nas igrejas neopentecostais, ofícios fúnebres celebrados em seus templos. O pastor da Igreja da Graça, ao ser perguntado sobre como a morte era tratada pela igreja, respondeu-nos de uma maneira bastante interessante, demonstrando certo distanciamento emocional e naturalizando-a:

Primeiro lugar, quando alguém da igreja veio a falecer, primeira atitude que nós tomamos é procurar dar um apoio pra família. O apoio financeiro? Não, não o apoio financeiro, mas o apoio espiritual, 
apresentando pra família que aquela pessoa, ela teve a obra consumada na terra. Ela amou a Deus, ela confiou em Deus, então ela tá num lugar até melhor do que aqueles que ainda estão sob a terra. Passa esse lado pras pessoas. E quanto à morte, a gente vê a morte assim... é algo natural porque o homem foi criado do pó da terra e o próprio Deus disse que ao pó da terra ela vai tornar. Então, é a morte fisica, porque eu acredito que não existe morte espiritual. (...) Então, a morte, o corpo descer pra terra, isso nós passamos pro povo que é uma coisa normal. E acredito que quem crê nisso não tem nem medo da morte.

Embora ele fale sobre apoio espiritual, fica clara a ênfase que dá ao lado natural da morte. Não há um ritual que a dramatize. Em todos os cultos observados, não houve qualquer alusão à morte de qualquer pessoa ou mesmo nenhum culto que enfocasse o morrer, o fim da vida. Ao contrário, os cultos enfatizavam a vida, a cura, o bem-estar do corpo e da alma aqui na terra. Na Igreja Presbiteriana, apesar de ser bem menor em termos numéricos que a Igreja Internacional da Graça de Deus, ouvimos por várias vezes anúncios sobre o falecimento de membros da igreja e de seus parentes. A morte, por muitas vezes, foi tema do sermão do pastor presbiteriano, assunto seguido pelo alento da vida eterna.

Os presbiterianos não vêem a morte como algo natural. Ao contrário, eles dizem que não fomos criados para morrer. A morte é vista como fruto de nossa desobediência aos mandamentos divinos. Como eles dizem, a morte é o "salário do pecado". O jardim do Éden é evocado e Adão, como representante da raça humana, tentado pelo diabo, em forma de serpente, e seduzido por Eva, sua mulher, simboliza o erro fatal que levou a morte a todos os homens. Por ele entrou a morte, algo não natural, mas provocado pelo pecado da desobediência a Deus. Completamente desnaturalizada, a morte é ritualizada entre os presbiterianos. Os cultos fúnebres dos membros mais assíduos e ativos da igreja são feitos em um dos salões das dependências da Igreja Presbiteriana. Neles, a morte é pranteada e o processo ritual alcança seu auge na mensagem consoladora do pastor da igreja. Os questionamentos têm um espaço, nesse momento, para que sejam feitos, mas nunca em forma de revolta contra Deus. A observação de quatro rituais de morte demonstra que os presbiterianos se utilizam da categorização da sociedade inclusiva sobre algumas questões associadas ao morrer. A forma como se morre, a faixa etária em que se morre e o gênero do morto parecem ser as categorias mais fortes a serem levadas em conta diante do fato, como faz a sociedade, de maneira geral. Por coincidência, observamos um ofício fúnebre de uma mulher, bem idosa, de uma criança e de dois senhores de meia idade. A reação dos membros da igreja diante das quatro mortes foi diferente, embora o processo ritual tivesse, basicamente, o mesmo formato. Evocamos as palavras do historiador Michel Vovelle (1996, p. 13) sobre essa categorização da morte:
Avaliar o peso da morte sofrida, nesse primeiro nível, é apreciar os parâmetros, os componentes sociais desse corte, a começar pela diferença de sexo, de acordo com a idade (morte da mulher, morte do homem, morte da criança) desigual e, sobretudo, desigualmente sentida.

A morte da mulher idosa, com aproximadamente 85 anos, uma pessoa que fora extremamente ativa na igreja, foi chorada pelos presbiterianos de maneira mais contida. As pessoas pareciam mais conformadas por causa da idade daquela mulher. O culto fúnebre foi celebrado logo depois do culto tradicional da igreja, no domingo à noite. Foram cantados os hinos preferidos da idosa em questão e um dos pastores fez uma breve mensagem, bastante emotiva, mas também calma, enfatizando sua vida consagrada a Deus e o exemplo como serva de Deus que ela deixava à igreja. Foram exaltadas também suas virtudes como mãe e esposa dedicada, o que evidencia a questão de gênero presente também no morrer.

No culto fúnebre do senhor, com mais ou menos 49 anos, cuja família era bastante assídua e participativa na igreja, a comoção foi bem maior. Ele ocupava o cargo de presbítero da igreja e os presbiterianos pediam por sua cura há dois anos. Os questionamentos foram inevitáveis, apesar, de como já dito, não terem o tom de revolta contra Deus. Dois corais da igreja, um de adultos e um de jovens e adolescentes, cantaram no funeral. As pessoas expressavam claramente a dor da perda por meio de abraços e lágrimas. Um dos parentes do morto pediu a palavra e disse que certamente seria o melhor Natal que o presbítero passaria, já que a morte aconteceu dois dias antes do dia 25 de dezembro. O que dizer nessa hora? Deus não ouviu a oração dos seus filhos? A resposta, tão esperada, veio pela boca do pastor. A mensagem por ele pregada falava sobre os mistérios dos desígnios de Deus, do gozo da vida celestial e da alegria, no porvir, do reencontro. A palavra do pastor enfatizava esse reencontro. O morrer, assim, é visto como um período de transição, um breve período no tempo da eternidade em que se atravessa uma ponte e, do outro lado, aguarda-se o reencontro, o prazer de uma nova visão da vida, sem doença, sem dor, sem tristeza. Este, no entanto, não é um simples reencontro. Significa o âmago de uma esperança que se funda no encontro, na eternidade, de todos os filhos de Deus, todos os escolhidos.

A corporeidade, nessa questão, ganha um peso extraordinário entre os presbiterianos que, curiosamente, colocamna em segundo plano durante a vida aqui na terra. Os corpos serão, na teologia do protestantismo histórico, revestidos de imortalidade, serão ressuscitados e receberão outra estrutura material, um material inacabável, impecável (no sentido literal da palavra), incorruptível, eterno. Há, então, certo desprezo ao corpo mortal. Várias vezes, nos cultos funerários, o pastor oficiante referiu-se à pessoa morta como "este corpo mortal" como sendo uma cápsula vazia, apenas um recipiente. Ali estava apenas a representação da pessoa. Não era mais ela. No entanto, o corpo não é desprezado pelos presbiterianos por não conter mais a alma. No Manual Presbiteriano 
(Igreja Presbiteriana do Brasil, 1997), que versa, entre outras coisas, sobre a Constituição Presbiteriana do Brasil, há um capítulo, o décimo, que trata sobre funerais. Segundo esse capítulo, os Artigos $22^{\circ}$ e $23^{\circ}$ estabelecem como o corpo deve ser tratado e como deve se portar o presbiteriano no funeral. Vejamos:

O corpo humano, mesmo após a morte, deve ser tratado com respeito e decência. Chegada a hora marcada para o funeral, o corpo será levado com decência para o cemitério e sepultado. Durante essas ocasiões solenes, todos os presentes devem portarse com gravidade. O oficiante deverá exortá-los a considerar a fragilidade desta vida e a importância de estarem preparados para a morte e para a eternidade (Igreja Presbiteriana do Brasil, 1997, p.119).

A teologia presbiteriana, portanto, aponta para a fragilidade da vida terrenal e, assim, estabelece um código de negação e inferioridade dos prazeres carnais que, por serem temporários e efêmeros, em comparação com o gozo do eterno, devem dar lugar a uma vida consagrada, cheia de pudores, tabus, proibições e interditos que reafirmem à alma usufruir o céu e a ressurreição de um corpo que se fará perfeito. Esse conforto, recriação e rememoração da esperança, contudo, não anulavam a dor do momento do adeus nos rituais funerários observados. $\mathrm{O}$ fechar do caixão levou a igreja às lágrimas, como se ela fosse uma grande família que perdeu, de fato, um dos seus membros. E é assim que os presbiterianos se vêem, como uma grande família em que os laços espirituais de parentesco (todos são filhos de Deus e, portanto, irmãos na fé) são intensamente valorizados. Os atributos de bom marido e bom pai foram ressaltados no ofício fúnebre desse senhor. À família, os pastores pediam o apoio da igreja nesse momento difícil.

$\mathrm{O}$ abalo que causara a morte desse senhor aos presbiterianos foi visível. Por algum tempo, algumas notas no boletim da igreja tentavam consolar seus membros e trazer à memória a pequenez desse fato diante da vida eterna, um tempo ininterrupto, sem fim, no céu para aqueles que foram feitos filhos de Deus. Mas, ao lado disso, os presbiterianos convivem com dúvidas, com questões que não têm explicação nem resposta. Nos anos em que fizemos a observação participante, a igreja foi golpeada por mais duas mortes.

A morte de uma criança, de 12 anos de idade, já relatada, trouxe de volta o fantasma dos questionamentos. Doente desde seu nascimento, a igreja acompanhava os progressos daquela criança. Todos compartilharam da conversão daquele menino e se emocionavam com a forma pela qual ele se comportava na igreja, nos momentos litúrgicos, mostrando de maneira espontânea sua relação com o sagrado. Filho de pessoas muito populares na igreja, foi hospitalizado às pressas e veio a falecer, depois de 12 anos de luta pela vida e de contar com as orações de todo o grupo religioso.

$\mathrm{O}$ ofício fúnebre da criança foi marcado por questionamentos feitos abertamente. Pudemos observar as pessoas se perguntando sobre qual o propósito de Deus em permitir a morte daquela criança que fazia tantos progressos em termos de recuperação de movimentos, fala, dentre outros. Além disso, alguns pareciam pensar alto ao comentarem sobre a possibilidade de provação divina dada à família com o ocorrido. Outros, ainda, diziam que havia sido melhor para a criança e para a família que houvesse acontecido aquele desfecho, referindo-se ao desgaste que provocavam as limitações da criança aos familiares.

O salão, naquele dia, pareceu-nos um lugar de controvérsias, análises, questionamentos. Observamos que ninguém ali estava tranquilo ou conformado. A movimentação era intensa. A conversa também. No momento da mensagem, três pastores falaram, entremeando as falas com músicas, as prediletas da criança. Todos falaram sobre ela com muito carinho e reafirmaram a esperança de reencontro no céu. Nas falas, o questionamento esteve presente. Em uma das mensagens, o pastor disse não entender, mas aceitar o propósito de Deus. A explicação para aquela morte foi substituída pela lembrança do que deve esperar o povo de Deus aqui na terra, ou seja, o futuro celestial. A dramatização não terminou aí. O pai da criança tomou a palavra e fez um histórico da vida do filho, desde seu nascimento. Ele parecia mostrar o quanto Deus estava fazendo-o forte diante da morte do filho. Enquanto falava, as pessoas choravam muito. A pregação do evangelho também foi feita pelo pai, que fez um apelo às pessoas que ainda não haviam se convertido que o fizessem, para também usufruírem das benesses da vida celestial.

A idéia de pureza associada à imagem da criança também se fez presente no culto fúnebre e a precocidade da morte foi pensada como um ganho, não uma perda, no sentido de que quanto mais cedo ocorre a morte, mais cedo o filho de Deus gozará do paraíso celestial. A "sorte" está ao lado de quem partiu cedo e não dos que ali ainda aguardam a redenção completa do corpo e da alma. Isso não implica o antegozo do céu, ou seja, gozá-lo por meio da esperança e da fé. Mas nada se compara à plenitude, para os presbiterianos, do final para o recomeço na eternidade.

A morte de outro senhor também foi dramatizada. Ele estava doente e sucumbiu diante de um câncer. A família, também popular na igreja e considerada como um exemplo de fé, olhava para o morto de uma maneira que parecia fazer a mesma pergunta: "Por que Deus não o curou?". As três mulheres da família desse senhor, a esposa e as filhas, sentadas ao lado do caixão, ouviam os hinos atentamente, cantados pelos membros da igreja. $\mathrm{O}$ pastor celebrou o ofício fúnebre e interrompeu sua fala em um momento de emoção. Ele falava como aquele homem era alegre e como alegrava as pessoas da igreja. O reencontro foi mencionado novamente nesse culto. A negação da morte como fim era evidente. A idéia da vida na terra como uma passagem torna-se forte nesses momentos.

"Se Deus quiser, vamos todos nos reencontrar", com essa fala, o pastor reafirmava o destino de todos ali. Este mundo é um tempo do ainda-não, é o tempo da esperança, de uma espera compartilhada pelos que crêem e que vivem 
no meio de um dilema, o do poder de Deus, por um lado, e o do querer de Deus, por outro. Diante disso, a fé dos presbiterianos passa, necessariamente por esse crivo, por essa decisão ilógica de um Deus que tudo pode, mas que tem seu querer que extrapola o entendimento do fiel, às vezes, atendendo-o e muitas vezes não.

Os neopentecostais não admitem esse querer divino que vai além da fé. Se algo pedido não acontece, necessariamente algum espírito maligno interferiu, agindo na vida do crente e desviando a generosidade divina ou, ainda, houve falta de fé por parte daquele que pediu a bênção. Não há espaço para o talvez. Para os crentes da Igreja Internacional da Graça de Deus, o próprio Deus já deu tudo o que eles querem. É só "tomar posse" da bênção. Sobre a idéia de "posse", categoria mais fundamental do que chama de seitas populares pentecostais, Gomes (1996, p. 231) diz o seguinte:

Tomar posse, portanto, não significa outra coisa senão realizar aquilo para o qual se está destinado. As coisas são "nossas” enquanto Deus as fez para nós, para delas fruirmos. Vir a possuir, portanto, significa bem mais uma reintegração de posse, um ter à disposição aquilo que nos é devido por direito de criação.

Ao dissertar sobre a Igreja Universal do Reino de Deus e sua teologia de que a divindade se torna escrava de suas promessas aos fiéis, Campos (1997, p. 369) deixa claro esse traço típico da exigência das benesses divinas, no meio neopentecostal:

Cumpridas todas as exigências, com muita fé e nenhuma dúvida, o milagre só tem que acontecer. Basta exigir de Deus a realização de tais desejos. Mas, e se não der certo? Ainda dentro dessa lógica, a culpa é do fiel, que deve ter tido falta de fé em algum momento do processo.

Quanto à morte, ela não pode ser considerada uma negação de Deus ao pedido de cura do grupo religioso. Ela apenas acontece. No nível das significações, a morte ocupa um espaço simbólico muito pequeno. O presente e as vitórias conseguidas pelos viventes se sobrepõem a esse fato da natureza. O que parece ficar evidente é que a morte é o único compartimento da vida, entre os neopentecostais, que escapa do processo de magicização por eles implementado (Rivera, 2001). Não há nada de mágico na morte. Ela é um fato, puro e simples para eles. Mais que isso, a morte pode encerrar uma vida sem bênçãos e isso é visto como um fracasso para o fiel. Por isso, é preciso, segundo esses evangélicos, buscar a bênção divina para o presente, correndo contra o relógio da morte. Vejamos o que diz sobre isso um obreiro (termo usado para designar aqueles que são nomeados para fazerem parte da liderança da igreja, juntamente com o pastor) da Igreja
Internacional da Graça: "Uma hora você vai receber essa bênção, mas você tem que perseverar. Eu creio que você não vai receber sua bênção na sua morte. Tem que receber aqui pra desfrutar".

A idéia da vida na terra como uma passagem, acima mencionada, não retira do presbiteriano a responsabilidade de ter uma vida exemplar. Aliás, uma boa passagem para alcançar o céu depende também do curso de sua vida aqui na terra. A ética protestante pode ser vista nesse sentido. A vida é pensada como passageira, mas deve ser vivida de acordo com os dogmas divinos. O depoimento de um presbiteriano entrevistado traz o teor dessa ética protestante:

A vida aqui na terra? Pra mim, é uma passagem aqui, né? A gente tá aqui pra... viver de forma boa, de forma com que Deus escreve... na Biblia, de viver de forma correta, de forma reta, né? A gente tem que ser... não... pelo fato de ser uma passagem a gente fazer tudo que a gente quer, ter todos os prazeres e deixar com que... no final da vida a gente... tome conhecimento disso. Não, não é isso. É a gente... viver... do melhor jeito, da melhor maneira, como se fosse... o último dia da sua vida. Viver de forma bem feliz.

Não poderíamos deixar de contar, neste trabalho, uma experiência vivida, muito marcante, no que se refere à morte entre os presbiterianos. Um senhor da Igreja Presbiteriana encontrava-se muito doente, vítima de câncer. Durante os seis meses do agravamento da doença, pudemos conversar muitas vezes com ele. Fomos visitá-lo, um mês antes de morrer, depois de retornar de uma longa internação hospitalar. Chegamos à frente de sua casa e ele estava acomodado em uma cadeira de balanço na calçada, embaixo de uma árvore. Sua magreza causava uma sensação terrível de morte e nos fazia suar frio. Ali estava ele, inerte, com um cobertor cobrindo seu corpo frágil, numa manhã de vento frio. Aproximamo-nos dele e seus olhos estavam cerrados. Sentimo-nos incomodados com aquela quietude, aquele silêncio profundo. Então, delicadamente, o tocamos e o cumprimentamos. Os olhos abriram-se vagarosamente. Um pequeno sorriso foi por ele esboçado, mas logo voltou à quietude e os olhos se fecharam novamente. Insistimos em quebrar o silêncio e lhe perguntamos: "Em que o senhor está pensando?", a resposta, para nossa surpresa, foi imediata: "Pensando na morte porque a vida é certa". O trocadilho, por um instante, não nos pareceu proposital e, então, ingenuamente dissemos a ele: “Não é: 'na vida porque a morte é certa'?”. Ele nos disse, suavemente, mas com convicção: "não". Esboçou um sorriso, novamente, e seus olhos se fecharam. Nenhuma resposta poderia ser tão sintetizadora da postura dos presbiterianos ante a morte e nenhum outro olhar de tamanha calma e aceitação do que estava por vir poderia dizer tanto sobre a noção de esperança desses evangélicos. 


\section{Considerações finais}

A morte entre presbiterianos e neopentecostais é vista de forma bastante distinta. Para os presbiterianos, ela aparece como uma transição, dolorosa e ritualizada, para a vida eterna e para o posterior reencontro dos que aguardam a redenção não só da alma, mas de toda a terra, que deve se fazer nova e restaurada, por meio da segunda vinda de Jesus Cristo. A esperança constrói-se sobre essa base teológica, evocada nos rituais funerários desse grupo religioso. A idéia de ressurreição é central na teologia presbiteriana, visto que possibilita ao fiel reafirmar sua fé na esperança da redenção completa do ser humano, por meio da ação divina que transformará os corpos mortais em imortais e incorruptíveis.

Para os neopentecostais, a morte aparece como um fato natural que significa, de certa forma, o fim de um fluxo constante de bênçãos que o fiel deve buscar em sua vida presente. Por isso, a morte não tem espaço como um ritual religioso nos cultos ou eventos desse grupo, mas sim os rituais de cura divina e de busca da prosperidade financeira na vida terrena, o que poderia ser caracterizado por um "milenarismo intramundano" (Campos, 2000) desses religiosos. O pós-morte é, para os presbiterianos, a esperança de uma vida sem dores, tristezas e doenças. Para os neopentecostais, o pós-morte não ocupa um lugar central, mas sim o "já" que deve ser uma caminhada de ascensão social e um tempo de fruição das bênçãos divinais no presente, que se fazem visíveis por meio da saúde física e de uma melhora significativa da condição financeira.

O “ainda-não" para os presbiterianos significa, na visão neopentecostal, a privação do que tem Deus a oferecer aos seus filhos no tempo presente. Curiosamente, a morte não é, na doutrina neopentecostal, revestida de emocionalidade e/ou emocionalismo, traço característico de todos os rituais desses evangélicos. Entre os presbiterianos, a morte transforma-se em um ritual profundamente marcado pela expressão da emoção, norteada, contudo, pela razão doutrinária da esperança e do reencontro pós-morte no céu.

Enfim, pode-se ver que há entre esses dois grupos religiosos os mesmos elementos de fé, mas dispostos de maneira diferentes na escala de valores e desejos prioritários. Os neopentecostais valorizam a ação de Deus na vida do fiel que se mostra por meio da prosperidade física e financeira, no plano do imediato, da vida na terra, demonstrando uma fé afinada aos moldes do mercado capitalista. Os presbiterianos não negam as bênçãos de Deus nessas áreas, mas focalizam sua fé no "outro" mundo, o da salvação da alma e da morada eterna com Deus, nos lugares celestiais. A vida, aqui na terra, para eles, é apenas um tempo de transição para a obtenção da plenitude do significado da criação e da vida.

\section{Referências}

Campos, L. S. (1997). Teatro, templo e mercado: Organização e marketing de um empreendimento neopentecostal. Petrópolis, RJ: Vozes.

Campos, L. S. (2000). O milenarismo intramundano dos novos pentecostais brasileiros. Estudos de Religião, 18, 99-120.

Freston, P. (1994). Breve história do pentecostalismo brasileiro. In A. Antoniazzi (Org.), Nem anjos nem demônios: Interpretações sociológicas do pentecostalismo. Petrópolis, RJ: Vozes.

Geertz, C. (1978). A interpretação das culturas. Rio de Janeiro: Jorge Zahar.

Gomes, W. (1996). Nem anjos nem demônios. In A. Antoniazzi, C. L. Mariz, I. Sarti, J. Bittencourt Filho, P. Sanchis e cols. (Orgs.), Nem anjos nem demônios: Interpretações sociológicas do pentecostalismo (pp. 225270). Petrópolis, RJ: Vozes.

Gutiérrez, B. F. (1996). Os pentecostais na América Latina: Um desafio às igrejas históricas. In B. Gutiérrez \& L. S. Campos (Orgs.), Na força do espírito: Os pentecostais na América Latina, um desafio às igrejas históricas (pp. 129-149). São Paulo: Associação Literária Pendão Real.

Loureiro, A. M. L. (2000). A consciência da morte e a alienação sobre o morrer. In A. M. L. Loureiro, A velhice, o tempo e a morte (pp. 77-80). Brasília, DF: EdUnB.

Igreja Presbiteriana do Brasil. (1997). Manual presbiteriano (13a ed.). São Paulo: Cultura Cristã.

Mariano, R. (1999). Neopentecostais: Sociologia do novo pentecostalismo no Brasil. São Paulo: Edições Loyola.

Mendonça, A. G. (1995). O celeste porvir: A inserção do protestantismo no Brasil. São Bernardo do Campo, SP: EdUMESP.

Mendonça, A. G. (2000). O protestantismo latino-americano entre a racionalidade e o misticismo. Estudos de Religião, 18, 69-98.

Pinezi, A. K. M. (2006). A noção de esperança e suas implicações para a vida: Análise comparativa entre dois grupos evangélicos. Revista Jurídica UniCOC, 1, 7-12.

Pinezi, A. K. M. (2007). O mundo reencantado: A religião na contemporaneidade. In C. L. de C. Penteado \& S. J. da Silva (Orgs.), Diálogo de saberes para a ação cidadã (pp. 79-98). Santo André, SP: Escritório da Mídia.

Rivera, P. B. (2001). Tradição, transmissão e emoção religiosa: Sociologia do protestantismo na América Latina. São Paulo: Olho d'água.

Romanelli, G. (1998). A entrevista antropológica: Troca e alteridade. In G. Romanelli \& Z. M. M. Biasoli-Alves (Orgs.), Diálogos metodológicos sobre prática de pesquisa (pp. 119-133). Ribeirão Preto, SP: Legis Summa.

Romanelli, G., \& Pinezi, A. K. M. (2003). O mal exorcizado: Cura divina entre os neopentecostais da Igreja Internacional da Graça de Deus. Impulso, 14, 65-73. 
Vovelle, M. (1996). A história dos homens no espelho da morte. In H. Braet \& W. Verbeke (Orgs.), A morte na Idade Média. São Paulo: EDUSP.

Ana Keila Mosca Pinezi é Professora Adjunta II do Centro de Engenharia, Modelagem e Ciências Sociais Aplicadas da Universidade Federal do ABC, campus Santo André.

Recebido: 04/07/2008

$1^{a}$ revisão: 24/01/2009

$2^{a}$ revisão: $29 / 02 / 2009$

Aceite final: 01/06/2009 